\title{
THE USE OF CHLOROPHYLL FLUORESCENCE TO IDENTIFY CHEMICAL AND ENVIRONMENTAL STRESS IN LEAF TISSUE OF THREE OAK (QUERCUS) SPECIES
}

\author{
By Glynn C. Percival
}

\begin{abstract}
During their lifetime, urban trees are susceptible to a range of environmental and chemical stresses that can result in tree decline. Chlorophyll fluorescence has been used as a nondestructive and noninvasive means of quantifying damage to the leaf photosynthetic system of deciduous and evergreen trees. Aims of this investigation were to determine whether there were unique chlorophyll fluorescence profiles for different chemical (salt, herbicide) and environmental (heat) stresses in leaf tissue of three oak (Quercus) species. Results demonstrate that alterations in the OJIP curve as a measure of electron transport within the leaf plastoquinone pool of photosystem II could be used to identify tree decline due to herbicide and heat but not to salt damage. The benefits of this system to make rapid, stress-specific diagnosis in the field for professionals involved in urban tree management are discussed.
\end{abstract}

Key Words. English oak; evergreen oak; heat; herbicide; leaf tissue damage; red oak; salinity; stress detection; Quercus ilex; Quercus robur; Quercus rubra.

Urban landscapes present an environment detrimental to the biology of trees due to soil deoxygenation, compaction, air pollution, and de-icing salt stresses. These stresses limit the amount of carbohydrates available for growth and maintenance and reduce nutrient and water uptake, resulting in leaf chlorosis, branch dieback, and, ultimately, death.

Initial symptoms of tree decline are generally manifest as leaves yellowing, which is a visible indicator that arborists interpret to assess tree vitality (Percival 2004). Appropriate remedial action at this stage may alleviate the problem prior to physical deterioration of tree structure. Physiological tests such as shoot and root electrolyte leakage, root growth potential, leaf starch concentration, leaf chlorosis, and photosynthesis have been successfully used to identify low vigor or damaged plants; however, none of these systems can identify the causative stress or stresses responsible for the visible signs of tree decline (Percival 2004; Richardson et al. 2004). Consequently, identifying the actual cause of tree decline (environmental stress, chemical damage, inappropriate soil conditions, etc.) can be costly, time consuming, and labor intensive.
Chlorophyll fluorescence has been used to provide a rapid, nondestructive diagnostic method for detecting and quantifying damage to the leaf photosynthetic apparatus in ornamental and coniferous trees in response to environmental stress (Palta 1992; Sestak and Stiffel 1997; Percival 2004). The technique measures changes in chlorophyll $a$ fluorescence due to altered photosystem II (PSII) activity, caused directly or indirectly by stress.

Most commercially available fluorimeters commonly measure the minimal, maximal, and variable chlorophyll fluorescence (Fo, Fm, and Fv, respectively, where Fv = Fm Fo). Ratios of the parameters Fv/Fm, Fo, and Fv/Fo provide estimates of various aspects of leaf photosynthetic and photochemical activities (Hong and Xu 1999; Yamane et al. 2000; Percival and Fraser 2002). In addition, many

fluorescence systems offer the flexibility to store intermediate data points at specific times within the 1-s fluorescence induction. For example, when a healthy leaf is suddenly illuminated after a period of darkness, a time-dependent fluorescence emission kinetic is observed, known as the Kautsky effect. Two parts to this induction kinetic can be distinguished: (1) the fast fluorescence rise to the maximum fluorescence, which is completed in 100 to $500 \mathrm{~ms}$, and (2) the slow fluorescence decrease to the steady-state level.

The analysis of the intermediate data points of the fast fluorescence rise forms the basis of what is termed the OJIP curve. In brief, all higher plants that contain chlorophyll as the main photosynthetic pigment (trees, shrubs, crops, grasses, etc.) exhibit a rise of chlorophyll fluorescence the first second after illuminating a dark-adapted sample that follows a universal OJIP curve (Figure $1^{*}$ ).

Within leaf tissue of all higher plants, a pool of specialized molecules known as plastoquinones exist that are involved in photosynthetic electron transfer between photosystems I and II. The two plastoquinone molecules responsible for electron transport are plastoquinone $A\left(Q_{A}\right)$, a one-electron carrier, and plastoquinone $B\left(Q_{B}\right)$, a one- or two-electron carrier. The initial chlorophyll fluorescence at O level reflects the minimal fluorescence yield when all 
plastoquinone $\left(Q_{A}\right)$ molecules are in the oxidized state. The end, or $\mathrm{P}$ level, corresponds to the state in which all $Q_{A}$ molecules are in the reduced state. Steps $\mathrm{J}$ and I occur between the $\mathrm{O}$ and $\mathrm{P}$ steps. The $\mathrm{O}$ to $\mathrm{J}$ phase results from the reduction of $Q_{A}$ to $Q_{A-}$ and is associated with the primary photochemical reactions of photosystem II. The intermediate step I and the final step P reflect the existence of fast- and slowreducing PQ centers. Consequently, the OJIP curve represents a measure of the plastoquinone pool within leaf tissue. Importantly, the OJIP curve changes its shape according to differing environmental stresses such as light intensity, temperature, drought, chemicals, or heavy metals and has been used to provide a stressspecific diagnosis (Govindjee 1995; Haldimann and Strasser 1999; Popovic et al. 2003).

Work by many researchers (Guisse et al. 1995; Cajanek et al. 1998; Haldimann and Strasser 1999; Georgieva et al. 2000), however, suffers from a number of limitations. In most instances, young seedling material of crop species has been the test species of choice, which may not reflect the leaf physiology and subsequent fluorescence responses of tree material acclimated to the harsh atmospheric conditions, such as elevated ozone or car exhaust pollutants, that can exist within a urban landscape. In addition, assessments of fluorescence have been conducted mainly under laboratory and glasshouse conditions, which do not reflect conditions under field or landscape environments. Finally, fluorescence responses in most cases were recorded with a few hours following stress treatments and do not provide long-term information as to how long fluorescence effects remain altered by environmental stresses (Srivastava et al. 1998; Lazar et al. 1999; Hong and Xu 1999; Yamane et al. 2000).

Aims of this investigation were to determine whether interpretation of a range of chlorophyll fluorescence responses could be used to distinguish between environmental (heat) and chemical (salt, herbicide) stress in foliar tissue of three oak (Quercus) species and determine the length of time that alterations to fluorescence responses were recorded before tree recovery. For the purposes of this investigation, stresses were applied to larger, cell-grown stock approximately 3 to 4 years old, rather than to seedling material grown under field, not glasshouse or laboratory, conditions.

\section{MATERIALS AND METHODS}

\section{Plant Material and Experimental Design}

The experiment used cell-grown stock of evergreen (Quercus ilex L.), English (Q. robur L.), and red oak (Q. rubra L.) obtained from a commercial supplier (Table 1). Trees were planted directly into the ground by hand in early November 2001 and left to establish throughout the 2002 growing season to overcome any potential effects of transplant shock. Five trees of each oak species were also potted into $4.5 \mathrm{~L}$ (1.2
Table 1. Physical characteristics of evergreen (Quercus ilex L.), English (Q. robur L.), and red oak (Q. rubra L.) after grading to ensure uniformity of stock for experimental purposes.

\begin{tabular}{llll}
\hline Attribute & Evergreen oak & English oak & Red oak \\
\hline Height $(\mathrm{cm})$ & $40.0(1.30)^{*}$ & $35.6(1.51)$ & $33.4(1.55)$ \\
Girth $(\mathrm{cm})$ & $2.3(0.11)$ & $1.33(0.09)$ & $1.16(0.09)$ \\
Height:girth ratio $(\mathrm{cm} / \mathrm{cm})$ & $17.4(0.66)$ & $27.8(1.50)$ & $28.8(1.54)$ \\
Shoot dry weight $(\mathrm{g})$ & $9.2(0.41)$ & $1.39(0.09)$ & $1.06(0.08)$ \\
Root dry weight $(\mathrm{g})$ & $8.2(0.48)$ & $3.98(0.25)$ & $2.88(0.15)$ \\
Shoot:root ratio $(\mathrm{g} / \mathrm{g})$ & $1.12(0.10)$ & $0.35(0.04)$ & $0.37(0.03)$ \\
Root area $\left(\mathrm{cm}^{2}\right)$ & $33.1(1.71)$ & $34.21(1.64)$ & $25.21(1.77)$ \\
\hline
\end{tabular}

*Values are mean and standard errors for 12 trees.

gal) pots with trial site soil and then planted into the ground to facilitate removal with minimal disturbance when trees were subjected to heat stress under controlled conditions at a later date.

The trial site consisted of a 2.5 ha $(6.25 \mathrm{ac})$ block located at the University of Reading Shinfield Experimental Site, Berkshire, UK. Planting distances were $1 \times 1 \mathrm{~m}(3.3 \times$ $3.3 \mathrm{ft}$ ). No watering was applied during the trial; however, on 10 May 2002, a broadcast application of granular N:P:K (29:7:9) fertilizer (Bartlett BOOST, The Doggett Corporation, Lebanon, NJ) was applied at $40 \mathrm{~g} / \mathrm{m}^{2}\left(0.13 \mathrm{oz} / \mathrm{ft}^{2}\right)$.

The soil was a sandy loam containing $4 \%$ to $6 \%$ organic matter; $\mathrm{pH}$ of 6.2; available $\mathrm{P}, \mathrm{K}, \mathrm{Mg}, \mathrm{Na}$, and $\mathrm{Ca}$ were 52 , 659.1, 175.2, 49.4, and 2,188 mg/L (0.007, 0.9, 0.02, 0.006, and $0.3 \mathrm{oz} / \mathrm{gal})$, respectively, at the time treatments commenced (May 2003). Weeds were controlled chemically using glyphosate (Roundup, Green-Tech, Sweethills Park, Nun Monkton, York, UK) from the day of planting in November 2001 to the cessation of the experiment in August 2003.

The experimental design was a randomized complete block with five single-tree replications. All treatments commenced under field conditions in early May 2003, when all oak species were in full leaf. To keep the physiological age of the leaves comparable throughout the experiment, measurements of chlorophyll fluorescence were made only on fully expanded, 21- to 28-day-old leaves. In all cases, five trees per treatment for each oak species were used for experimental purposes, with chlorophyll fluorescence measurements taken from six leaves (two from the top of the crown, two in the center, and two at the base) per tree. Leaves were tagged to ensure that the same leaves were measured throughout the experimental period.

\section{Treatments}

Prior to salt and herbicide sprays, polythene screens $1 \mathrm{~m}(3.3$ $\mathrm{ft}$ ) high were erected around each tree to prevent dispersal of sprays and possible cross contact with other trees. The base of the tree was covered with a $0.5 \mathrm{~m} \times 0.5 \mathrm{~m}(1.65 \times 1.65 \mathrm{ft})$ polythene mulch to prevent percolation of salt or herbicide into the soil. 
Salt Treatments. The salinity treatment consisted of $60 \mathrm{~g} / \mathrm{L}$ (8 oz/gal) sodium chloride distilled water solution ( $6 \% \mathrm{NaCl}$ solution) applied as a spray to the foliage of trees until runoff.

Herbicide Treatments. Foliar sprays of the herbicides atrazine (trade name Alpha Atrazine 50 SC) and DCMU (3(3,4-dichlorophenyl, trade name Diuron) were applied until runoff using a hand-sprayer at a concentration of $200 \mu \mathrm{M}$.

Heat Treatment. Heat damage to leaf foliar tissue was achieved by gently lifting five trees per species previously potted into 4.5 (1.2 gal) containers in 2001 from the ground and placing whole trees in darkness in a Merck environmental growth chamber for $5 \mathrm{~min}$ at a temperature of $50^{\circ} \mathrm{C}\left(122^{\circ} \mathrm{F}\right)$. Trees were then returned to the trial site and gently replanted into their original planting hole.

Chlorophyll Fluorescence. Fluorescence values were obtained by placing leaves in darkness for $30 \mathrm{~min}$ by attaching light-exclusion clips to the leaf surface of whole trees; chlorophyll fluorescence was measured using a HandyPEA portable fluorescence spectrometer (Hansatech Instruments Ltd., King's Lynn, UK). Measurements were recorded up to $1 \mathrm{~s}$ with a data acquisition rate of $10 \mu \mathrm{s}$ for the first $2 \mathrm{~ms}$ and of $1 \mathrm{~ms}$ thereafter. The fluorescence responses were induced by a red (peak at $660 \mathrm{~nm}$ ) light of $1,500 \mu \mathrm{mol} \mathrm{m} \mathrm{m}^{2} / \mathrm{s}$ photosynthetically active radiation (PAR) intensity provided by an array of six red lightemitting diodes.

Fluorescence values recorded were as follows:

1. Minimal fluorescence, or Fo, as a measure of the stability of the light-harvesting complex (Yamada et al. 1996).

2. The ratio of variable $(\mathrm{Fv}=\mathrm{Fm}-\mathrm{Fo})$ to maximal $(\mathrm{Fm})$ fluorescence ( $\mathrm{Fv} / \mathrm{Fm}$, which represents the maximum quantum yield of photosystem II), which in turn is highly correlated with the quantum yield of net photosynthesis (Demmig and Björkman 1987; BolharNordenkampf et al. 1989; Adams et al. 1995).

3. OJIP curves to monitor effects on plastoquinone electron acceptor reactions, plastoquinone pool size, and heterogeneity of photosystem II (shown on a logarithmic scale to allow visualization of the complete fluorescence transient) (Kruger et al. 1997; Srivastava et al. 1998; Lawlor 2001). All values were automatically calculated and graphed by the HandyPEA.

\section{Statistical Analysis}

Treatment effects on chlorophyll fluorescence were determined by one-way analyses of variance (ANOVA) following checks for normality and equal variance distributions. Data for each species were analyzed independently. Differences between treatment means were separated by the least significant difference (LSD) at the 95\% confidence level ( $P>$ 0.05) using the Genstat V program.

\section{RESULTS AND DISCUSSION}

Fv/Fm measurements from 0.78 to 0.85 are associated with healthy, nonstressed deciduous and evergreen trees (Demming and Björkman 1987; Maki and Columbo 2001; Percival 2004). Fv/Fm values of all species tested were within this range at day 0 , indicating that all trees tested in this investigation were healthy at the onset of the experiment and not suffering from any prior stresses (Figures 3a-3d).

Although the magnitude of the stress response and recovery from stress differed among species, effects on chlorophyll fluorescence followed similar trends in response to salt, heat, and herbicide damage; namely, Fv/Fm significantly decreased $(P<0.05)$ and Fo values significantly $(P<0.05)$ increased (Figures $2 \mathrm{a}-3 \mathrm{~d})$. Alterations to these fluorescence expressions represent damage to the photosystem II reaction centers and reduced photosynthetic capacity and photochemical efficiency (Yamada et al. 1996; Willits and Peet 2001) and concomitant damage or impairment of the leaf photosynthetic system and reduced photosynthetic $\mathrm{CO}_{2}$ fixation (Meinander et al. 1996; Lazar et al. 1997; Lu and Zhang 1998; Pospisil et al. 1998; Percival and Henderson 2003).

Salt damage to leaf tissue of woody plants includes disrupted stomata, collapsed cell walls, disorganized or disintegrated protoplasts, coarsely granular cytoplasm, disintegrated chloroplasts and nuclei, and disorganized phloem (Dobson 1991). In this investigation, maximal damage to the leaf photosynthetic system (greatest reductions in Fv/Fm and increases in Fo) were recorded between weeks 3 and 5 (Figures $2 \mathrm{a}$ and $3 \mathrm{a}$ ). Reductions in Fv/Fm at week 5 post-treatment indicated species salt tolerance in the order evergreen oak $>$ red oak $>$ English oak.

From week 5 onward, a steady recovery of the leaf photosynthetic system was recorded in all species until the cessation of the experiment (week 14). In the case of red and evergreen oak, Fv/Fm and Fo values at week 10 were comparable to those at day 0 , indicating full recovery of the leaf photosynthetic system from salt damage. In the case of English oak, values were not comparable until week 14, indicating a longer time period is necessary for recovery from salt damage (Figures $2 \mathrm{a}$ and $3 \mathrm{a}$ ).

Results of this investigation show that application of salt stress decreased the area of the OJIP curve but did not markedly change the shape of the curve affecting both the $\mathrm{O}-\mathrm{I}$ and I-P rises equally (Figure 4). For reasons of clarity, effects on the OJIP curves for each oak species are shown at day 0 and weeks 5 and 10. Interpretation of this response means salinity reduced electron transfer to the plastoquinone pool and plastoquinone pool size. Ultimately, these detrimental effects are manifest by reduced photosynthetic metabolism (Koves Pechy et al. 1998), photosynthetic 
capacity, and photochemical efficiency (Percival et al. 2003). For the purposes of this investigation, no distinguishable characteristics were observed with which to identify salt damage as the cause of tree decline using the fluorescence parameters Fo, Fv/Fm, and OJIP curves.

Photosynthesis is one of the most heat-sensitive processes in plant cells, leading to numerous changes of the structure and function of the photosynthetic apparatus (Georgieva et al. 2000). Within the photosynthetic system, it has been recognized that PSII is the most thermally labile component of the electron transport chain (Cajanek et al. 1998). Among partial reactions of PSII, the oxygen-evolving complex is particularly heat sensitive (Georgieva et al. 2000).

In response to heat, the greatest reductions in $\mathrm{Fv} / \mathrm{Fm}$ and increases in Fo were recorded at day 1 , indicating maximal damage to the leaf photosynthetic system (Figures $2 \mathrm{~b}$ and 3b). Reductions in Fv/Fm at day 1 post-treatment indicated species heat tolerance in the order evergreen oak $>$ English oak > red oak (Figure 3b).

From day 1 onward, a steady recovery of the leaf photosynthetic system was recorded in all species until day 18. In the case of red and evergreen oak, Fv/Fm and Fo values at day 12 were comparable to those at day 0 , indicating full recovery of the leaf photosynthetic system from heat damage. In the case of English oak, values were not comparable until day 14 , indicating that a marginally longer time period is necessary for recovery from heat damage (Figures $2 \mathrm{~b}$ and $3 \mathrm{~b}$ ).

In response to heat, a new K peak situated at about $200 \mu$ s (i.e., OKJIP) was observed in all three oak species (Figure 5). For reasons of clarity, effects on the OJIP curves for each oak species are shown at days 0,1 , and 8 (Figure 5).

Previous research has shown that formation of the $\mathrm{K}$ peak is linked to inhibition of the PSII oxygen-evolving complex (Lazar et al. 1997). Consequently, observation of the $\mathrm{K}$ peak in response to heat damage has been used as a diagnostic measure by which to quantify plants for horticultural and agricultural purposes based on their tolerance to elevated temperatures (Guisse et al. 1995; Lazar et al. 1997, 1999; Lazar and Ilik 1997). Higher temperatures in urban environments caused by the lack of transpirational cooling and increased heat convection and long-wave radiation from nonvegetative surfaces such as buildings and roads can be a problem (Montague et al. 1998). Under prolonged heat stress, especially during a hot, dry summer, tree limbs and trunks can break and fall-a phenomenon known as summer branch drop (Harris 1992). Such a response is undesirable in highly populated areas.

Results of this investigation indicate that alterations in the OJIP curve to an OKJIP curve can be detected using chlorophyll fluorescence analysis and used as a means of identifying tree decline due to elevated temperatures. This information would allow for remedial action prior to a tree becoming a danger to pedestrians and traffic. The alteration from an OJIP curve to an OKJIP curve appears to be a heat stress-specific response, as such alterations have not been recorded elsewhere in plants subjected to environmental stresses encountered in urban landscapes, such as elevated ozone, $\mathrm{CO}_{2}$, heavy metals, salt, light, and water (Meinander et al. 1996; Lazar et al. 1997; Lu and Zhang 1998; Pospisil et al. 1998).

Spray application with the herbicides Alpha Atrazine 50 and Diuron caused maximal damage to the leaf photosynthetic system between weeks 3 and 5, as manifest by the greatest reductions in $\mathrm{Fv} / \mathrm{FM}$ and increases in Fo values (Figures 2c, 3c, 2d, and 3d). From week 5 onward, a steady recovery of the leaf photosynthetic system was recorded in all species until the cessation of the experiment (week 21). In the case of English and evergreen oak, Fv/Fm and Fo values from week 13 were comparable to those at day 0 , indicating full recovery of the leaf photosynthetic system from herbicide damage (Figures $2 \mathrm{c}, 3 \mathrm{c}, 2 \mathrm{~d}$, and $3 \mathrm{~d}$ ). In the case of red oak, values were not comparable with day 0 even at the cessation of the experiment, indicating impairment of the leaf photosynthetic system at week 21 postherbicide application (Figures 2c, 3c, 2d, and 3d). This response and reductions in $\mathrm{Fv} / \mathrm{Fm}$ at week 5 following treatments showed species herbicide tolerance in the order evergreen oak $>$ English oak $>$ red oak (Figures 3c and 3d).

In response to herbicide application, a marked effect on the OJIP curve was observed. Irrespective of species, a maximum fluorescence intensity at about $2 \mathrm{~ms}$ around the same time that the J-step appears was observed (i.e., the OJIP curve becomes an O-J curve) (Figures 6 and 7). For reasons of clarity, effects on the OJIP curves for each oak species are shown at week 0, 5, and 13 (Figures 6 and 7).

Diuron and Alpha Atrazine 50 SC are soil residual herbicides with foliar-acting activity and are recommended for control of annual dicotyledons and annual grasses and perennials in amenity situations. In thylakoids of plant chloroplasts, a pool of plastoquinone molecules found in photosystem II are involved in electron transfer between photosystems I and II. Two plastoquinones-plastoquinone A $\left(Q_{A}\right)$, a one-electron carrier, and plastoquinone $B\left(Q_{B}\right), a$ one- or two-electron carrier-are involved in this electron transfer process. The active ingredients in Diuron and Alpha Atrazine 50 SC (DCMU and atrazine, respectively) act by displacing the secondary electron acceptor $Q_{B}$ from its binding site, effectively blocking the electron transport chain between $\mathrm{Q}_{\mathrm{A}_{-}}$and $\mathrm{Q}_{\mathrm{B}}$ (i.e., the I-P part of the OJIP curve), causing the maximum fluorescence from $\mathrm{O}-\mathrm{J}$ that was observed at week 5 of post-herbicide treatment (Guisse et al. 1995; Hall and Rao 1999) (Figures 6 and 7). Even at week 13 post-treatment, alterations to the OJIP curve (i.e., 
a maximal fluorescence to the J peak) were observed in most cases except one, evergreen oak sprayed with Diuron, for which OJIP curves reflected those at day 0 , indicating full recovery of the leaf photosynthetic system.

To date, alterations to OJIP curves following application of other herbicides commonly used in urban landscapes, such as glyphosate, chlorotoluron, paraquat, diquat, 2,4-D, mecoprop-P, and dichlorprop, have not been shown to induce the same alterations caused by the plastoquinone Bbinding herbicides used in this investigation (Korres et al. 2003; Popovic et al. 2003). This indicates that alterations to the OJIP curve (i.e., OJIP to OJ) can be used to identify tree decline caused by spray drift or inappropriate spraying with plastoquinone B-binding herbicides such as Atrazine, Diuron, and DCMU.

Although the physiological principles of chlorophyll fluorescence are complex, the operation of the fluorimeter used in this trial is simple. The practical advantages of using chlorophyll fluorescence include the fact that fluorescence measurements use a portable piece of equipment, measurements are nondestructive and noninvasive, and readings are obtained within $1 \mathrm{~s}$ following 20- to 30-min dark acclimation of a leaf using light-exclusion clips attached to the leaf surface. Consequently, many plants (60 to 80 per hour) can be evaluated and all data downloaded to a standard PC or laptop. The fluorescence software package can then be used to determine Fo and Fv/Fm and graph the OJIP curves.

Results demonstrated that fluorescence readings identified herbicide and heat damage as the primary cause of stress $24 \mathrm{~h}$ after treatments were applied (i.e., OJIP curves at $24 \mathrm{~h}$ were identical to those shown at week 5) (Figures 6 and 7) and that alterations to the OJIP curve could still be observed 12 days (heat) (Figure 5) and 13 weeks (herbicide) (Figures 6 and 7) later. Identification of the cause of tree decline based on visual observation alone (i.e., leaf yellowing and necrosis) would be impossible. In addition, laboratory methodologies to identify, for example, herbicide damage include doseresponse assays, radio-labeled compounds, or the measurement of metabolic processes at the cellular level. These identification systems can be labor intensive and expensive and require sophisticated analytical equipment and therefore are unsuitable for large numbers of plant samples (Korres et al. 2003). Fluorescence analysis may provide a cheaper and less labor-intensive alternative.

In conclusion, results of this investigation strongly indicate how interpretation of a range of fluorescence responses can be used to identify heat and plastoquinone-binding herbicide damage, but not salt, as a primary cause of tree decline in three oak species. Further work is ongoing to use this system to identify other forms of stress frequently encountered in urban environments that contribute to tree decline.

\section{LITERATURE CITED}

Adams III, W.W., B. Demmig-Adams, A.S. Verhoeven, and D.H. Barker, D. H. 1995. Photoinhibition during winter stress: Involvement of sustained xanthophyll cycle dependent energy dissipation. Aust. J. Plant. Physiol. 22:261-276.

Bolhar-Nordenkampf, H.R., S.P. Long, N.R. Baker, G. Oquist, U. Schreiber, and E.G. Lechner. 1989. Chlorophyll fluorescence as a probe of the photosynthetic competence of leaves in the field: A review of current instrumentation. Func. Ecol. 3:497-514.

Cajanek, M., M. Stroch, I. Lachetova, J. Kalina, and V. Spunda. 1998. Characterization of the photosystem II inactivation of heat-stressed barley leaves as monitored by the various parameters of chlorophyll a fluorescence and delayed fluorescence. J. Photochem. Photobiol. 47:39-45.

Demming, B., and O. Björkman. 1987. Comparison of the effect of excessive light on chlorophyll fluorescence $(77 \mathrm{~K})$ and photon yield of $\mathrm{O}^{2}$ evolution in leaves of higher plants. Planta 171:171-184.

Dobson, M.C. 1991. De-icing salt damage to trees and shrubs. Forestry Commission Bulletin 101.

Georgieva., K., T. Tsonev, V. Velikova, and I. Yordanov. 2000. Photosynthetic activity during high temperature of pea plants. J. Plant Physiol. 157:169-176.

Govindgee. 1995. Sixty-three years since Kautsky: Chlorophyll a fluorescence. Aust. J. Plant Physiol. 22: 131-160.

Guisse, B., A. Srivastava, and R.J. Strasser. 1995. The polyphasic rise of the chlorophyll a fluorescence (OKJIP) in heat stressed leaves. Arch. Sci. Geneve 48:147-160.

Haldimann, P., and R.J. Strasser. 1999. Effects of anaerobiosis as probed by the polyphasic chlorophyll $a$ fluorescence rise kinetic in pea (Pisum sativum L.) Photosyn. Res. 62:67-83.

Hall D.O., and K.K. Rao. 1999. Photosynthesis (6th ed.). Cambridge University Press. pp.174-180.

Harris, R.W. 1992. Arboriculture: Integrated Management of Landscape Trees, Shrubs, and Vines (2nd ed). Prentice Hall, New York, NY.

Hong, S.S., and D.-Q. Xu. 1999. Light-induced increase in chlorophyll fluorescence Fo level and the reversible inactivation of PSII reaction centers in soybean leaves. Photosyn. Res. 61:269-280.

Korres, N.E., R.J. Froud-Williams, and S.R. Moss. 2003. Chlorophyll fluorescence technique as a rapid diagnostic test of the effects of the photosynthetic inhibitor chlorotoluron on two winter wheat cultivars. Ann. Appl. Biol. 143:53-56. 
Koves Pechy, K., B. Biro, I. Voros, T. Takacs, E. Osztoics, and R.J. Strasser. 1998. Enhanced activity of microsymbiont-alfalfa system probed by the fast fluorescence rise OJIP, pp. 2765-2768. In Garab, P. (Ed.). Photosynthesis: Mechanisms and Effects: Proceedings of the International Congress on Photosynthesis, Budapest. Kluwer Academic Publishers, Dordrecht, The Netherlands.

Kruger, G.H.J., M. Tsimilli-Michael, and R.J. Strasser 1997. Light stress provokes plastic and elastic modifications in structure and function of photosystem II in camellia leaves. Physiol. Plantarum 101:265-277.

Lawlor, D.W. 2001. Photosynthesis (3rd ed.). Scientific Publishers Ltd., Oxford, UK.

Lazar, D., and P. Ilik. 1997. High-temperature induced chlorophyll fluorescence changes in barley leaves. Comparison of critical temperatures determined from fluorescence induction and from fluorescence temperature curve. Plant Sci. 124:159-164.

Lazar, D., P. Ilik, and J. Naus. 1997. An appearance of Kpeak in fluorescence induction depends on the acclimation of barley leaves to higher temperatures. J. Lumin. 72:595-596.

Lazar, D., P. Pospisil, and J. Naus. 1999. Decrease of fluorescence intensity after the K step in chlorophyll $a$ fluorescence induction is suppressed by electron acceptors and donors to photosystem 2. Photosynthetica $37(2): 255-265$.

Lu, C., and J. Zhang. 1998. Effects of water stress on photosynthesis, chlorophyll fluorescence and photoinhibition in wheat plants. Aust. J. Plant Physiol. 25:883-892.

Maki, D.S., and S.J. Colombo. 2001. Early detection of the effects of warm storage on conifer seedlings using physiological tests. For. Ecol. Manage. 154:237-249.

Meinander, O., S. Somersalo, T. Holopainen, and R.J. Strasser. 1996. Scots pine after exposure to elevated ozone and carbon dioxide probed by reflectance spectra and chlorophyll a fluorescence transients. J. Plant Physiol. 148:229-236.

Montague, T., R. Kjelgren, and L. Rupp. 1998. Surface energy balance affects gas exchange of three shrub species. J. Arboric. 24(5):254-262.

Palta, J.P. 1992. Mechanisms for obtaining freezing stress resistance in herbaceous plants, pp. 219-250. In Plant Breeding in the 1990s: Proceedings of a Symposium held at North Carolina State University.

Percival, G.C. 2004. Evaluation of physiological tests as predictors of young tree establishment and growth. J. Arboric. 30(2):80-92.
Percival, G.C., and G.A. Fraser. 2002. The influence of powdery mildew infection on photosynthesis, chlorophyll fluorescence, leaf chlorophyll and carotenoid content of three woody species. Arboric. J. 26(4):333-347.

Percival, G.C., and A. Henderson. 2003. An assessment of the freezing tolerance of urban trees using chlorophyll fluorescence. J. Hortic. Sci. Biotech. 78(2):254-260.

Percival, G.C., G.A. Fraser, and G. Oxenham. 2003. Foliar salt tolerance of Acer genotypes using chlorophyll fluorescence. J. Arboric. 29(2):61-66.

Popovic, R., D. Dewez, and P. Juneau. 2003. Applications of chlorophyll fluorescence in ecotoxicology: Heavy metals, herbicides, and air pollutants, pp. 151-184. In DeEll, J.R., and P.M.A. Toivonen (Eds.). Practical Applications of Chlorophyll Fluorescence in Plant Biology. Kluwer Academic Publishers, London, UK.

Pospisil, P., J. Skotnica, and J. Naus. 1998. Low and high temperature dependence of minimum Fo and maximum Fm chlorophyll fluorescence in vivo. Biochim. Biophys. Acta 1363:95-99.

Richardson, A.D., M. Aikens, G.P. Berlyn, and P. Marshall. 2004. Drought stress and paper birch (Betula papyrifera) seedlings: Effects of an organic biostimulant on plant health and stress tolerance, and detection of stress effects with instrument-based, non-invasive methods. J. Arboric. 30(1):52-60

Sestak, Z., and P. Stiffel. 1997. Leaf age related differences in chlorophyll fluorescence. Photosynthetica 33(34):347-369.

Srivastava, A.F., A. Jutter, and R.J. Strasser 1998. Action of the allelochemical fischerellin A on photosystem II. Biochem. Biophys. Acta 1364:326-336.

Willits, D.H., and M.M. Peet. 2001. Using chlorophyll fluorescence to model leaf photosynthesis in greenhouse pepper and tomato. Acta Hortic. 507:311-315.

Yamada, M., T. Hidaka, and H. Fukamachi. 1996. Heat tolerance in leaves of tropical fruit crops as measured by chlorophyll fluorescence. Scientia Hortic. 67:39-48.

Yamane, Y., T. Shikanai, Y. Kashino, H. Koike, and K. Satoh. 2000. Reduction of $Q_{A}$ in the dark: Another cause of fluorescence Fo increases by high temperatures in higher plants. Photosynthesis Res. 63:23-34.

Acknowledgments. The author is grateful for funding from the TREE Fund (Hyland Johns grant).

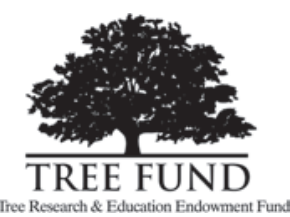




\author{
R.A. Bartlett Tree Research Laboratory, Europe \\ The University of Reading \\ 2 Early Gate \\ Whiteknights \\ Reading, RG6 6AU \\ United Kingdom
}

Résumé. Au cours de leur vie, les arbres urbains sont affectés par un éventail de stress environnementaux et chimiques qui peuvent provoquer leur déclin. La fluorescence de la chlorophylle a été utilisée en tant que méthode non invasive et non destructrice pour quantifier les dommages causés au système photosynthétique du feuillage des arbres feuillus et des conifères. Les objectifs de cette étude étaient de déterminer s'il existait des profils uniques de fluorescence de la chlorophylle des tissus foliaires chez les espèces de chênes face à divers stress chimiques (sel, herbicide) et environnementaux (chaleur). Les résultats ont conclu que cette méthode peut être utilisée pour identifier le dépérissement des arbres dû à l'herbicide et la chaleur, mais pas dans le cas de dommages par le sel. Les bénéfices de ce système pour effectuer un diagnostic rapide et spécifique d'un stress sur le terrain par des professionnels impliqués dans la gestion des arbres sont discutés.

Zusammenfassung. Während ihrer Lebenszeit sind Stadtbäume anfällig für eine Reihe von Umwelteinflüssen und chemischen Belastungen, die zu Baumrückgang führen können. Die Chlorphyllfluoreszenz (ChF) wurde als zerstörungsfreier Indikator zur Quantifizierung von Schäden am Photosynthesesystem von Laub- und Nadelbäumen benutzt. Ziele dieser Untersuchung war zu bestimmen, ob es bestimmte, einzigartige ChF-Profile für unterschiedliche chemische Schäden (Salz, Herbizide) und Umwelteinflüsse (Hitze) in den Blattgeweben von 3 Eichenarten gibt. Die Ergebnisse zeigten, dass Veränderungen in der OJIB-Kurve als ein Maß für Elektronentransport innerhalb des Photosynthesesystems II herangezogen werden können, um Baumsterben durch Herbizideinwirkung oder Hitzestress, aber nicht durch Salzeinwirkung, zu identifizieren. Die Vorteile dieses Systems schnelle stressspezifische Diagnosen im Feld zu treffen wird hier für Anwender in der urbanen Baumpflege diskutiert.

Resumen. Durante su tiempo de vida los árboles urbanos son susceptibles a un rango de estrés ambiental y químico que puede resultar en declinación. La fluorescencia de clorofila fue usada como un método no destructivo y no invasivo de cuantificar el daño del sistema fotosintético de la hoja de árboles deciduos y perennifolios. Los propósitos de esta investigación fueron determinar si hubo perfiles de fluorescencia únicos para diferentes químicos (sales herbicidas) y estrés ambiental (calor) en el tejido de la hoja en tres especies de encinos. Los resultados concluyen que las alteraciones en la curva OJIP, como una medida del transporte de electrones dentro de la hoja del fotosistema II, podría ser usado para identificar la declinación del árbol debido al herbicida y al calor, pero no al daño de la sal. Se discuten los beneficios de este sistema para hacer en el campo un diagnóstico rápido del estrés, para profesionales involucrados en el manejo de los árboles urbanos. 


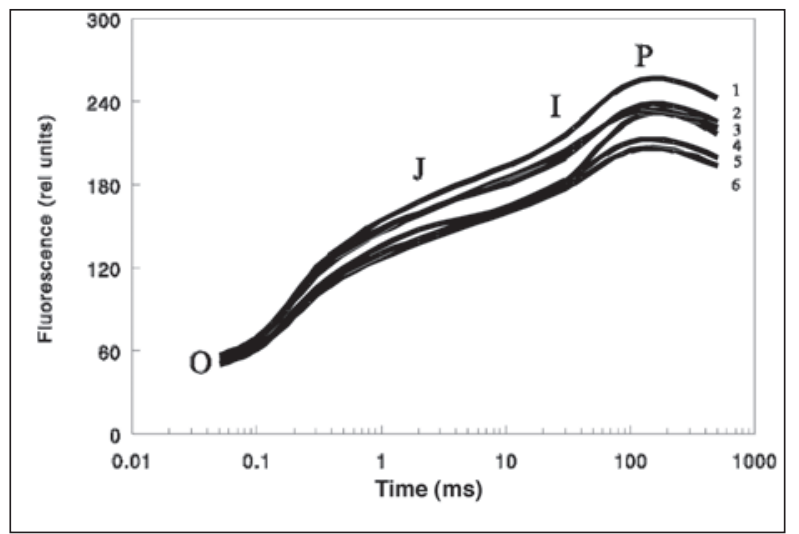

Figure 1. Polyphasic fluorescence pattern (OJIP curve) of six urban tree species: 1 -lime (Tilia $\times$ europea L.); 2-elm (Ulmus glabra Huds.);

3-Horsechestnut (Aesculus hippocastanum L.); 4-ash (Fraxinus excelsior L.); 5-cherry (Prunus avium L.); and 6-apple (Malus sylvestris (L.)

Mill.) the first second after dark illumination for $30 \mathrm{~min}$ (Percival, unpublished).

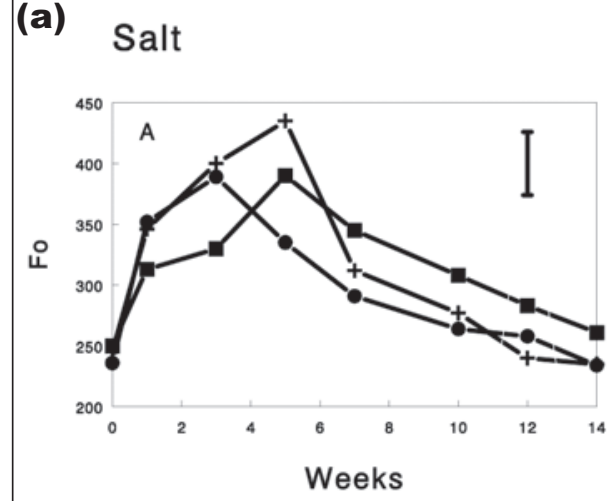

(c)

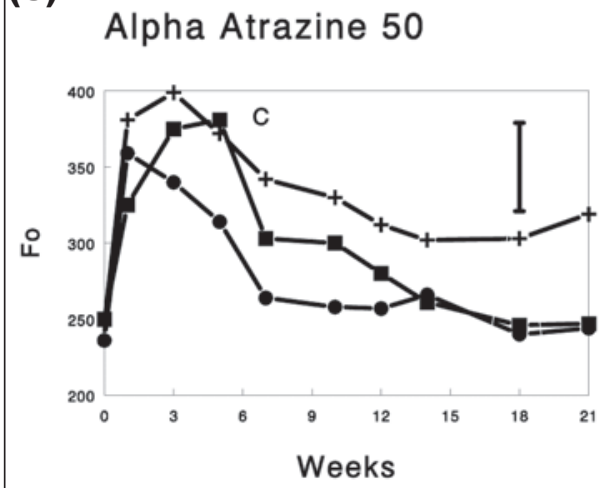

(b) Heat

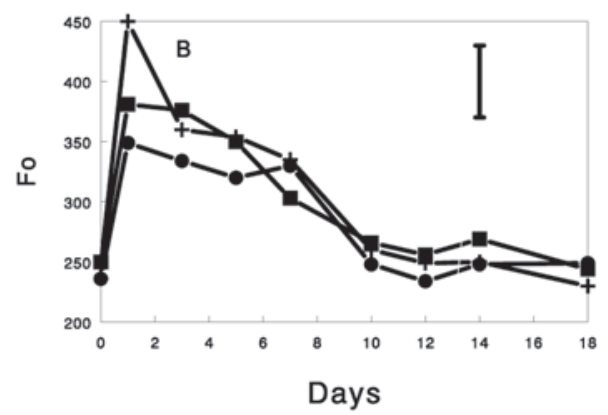

(d)

\section{Diuron}

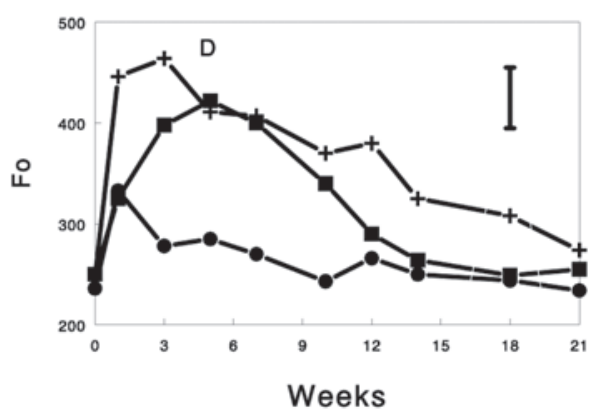

Figure 2. The influence of salt, heat, Alpha Atrazine 50, and Diuron on leaf chloroplast stability of three oak species as determined by chlorophyll fluorescence (Fo) measurements. $+=$ red oak, $\bullet=$ evergreen oak, $\square=$ English oak. All values are mean of five trees, six leaves per tree. $\mathrm{LSD}=$ least significant difference at $P \leq 0.05$. Species $={ }^{*}$, salt, heat, Alpha Atrazine 50, and Diuron treatment $=*$, species $\times$ treatment $={ }^{*}$. Note differing y axis. 


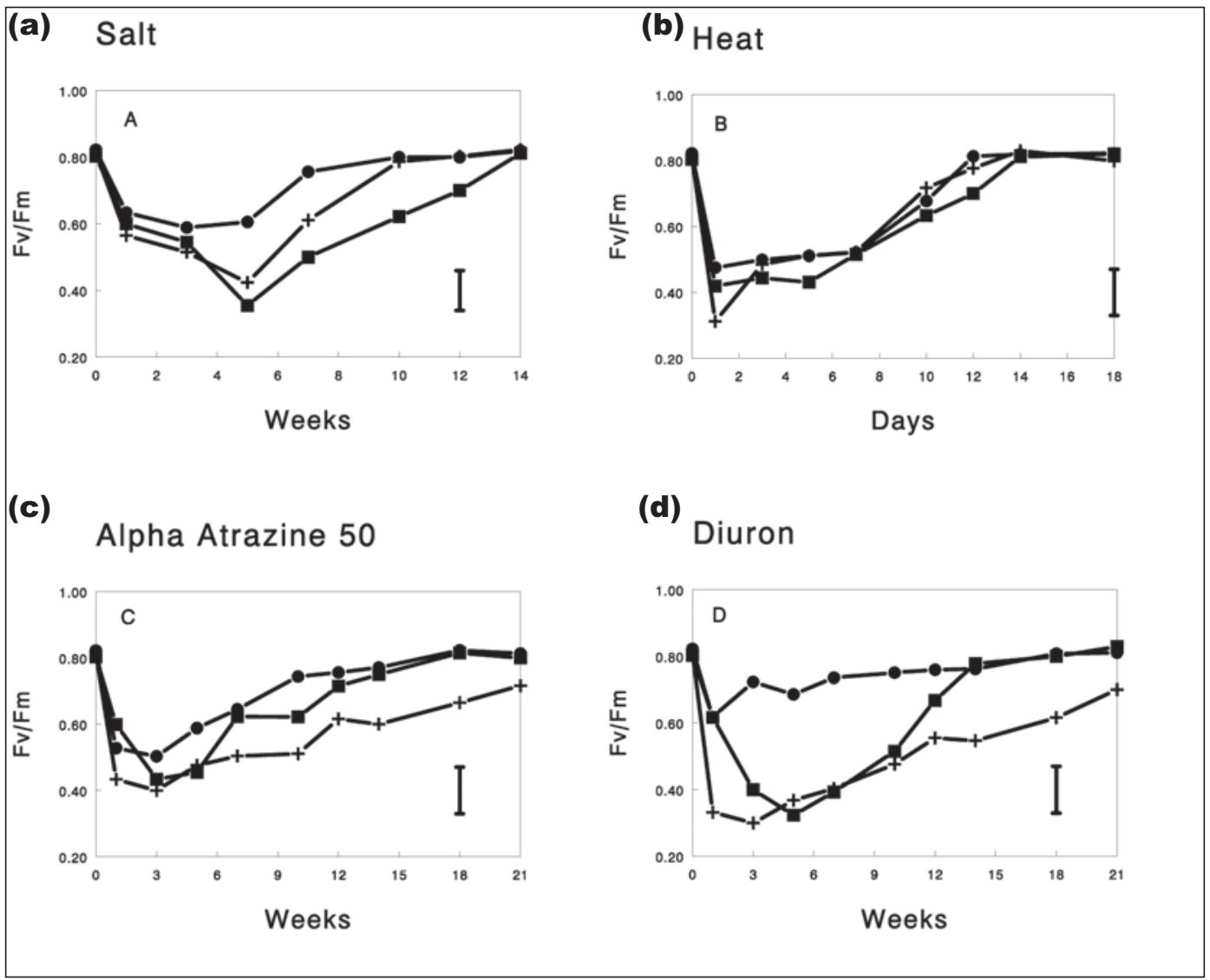

Figure 3. The influence of salt, heat, Alpha Atrazine 50, and Diuron on the maximum quantum yield of photosystem II of three oak species as determined by chlorophyll fluorescence $(\mathrm{Fv} / \mathrm{Fm})$ measurements. + = red oak, $\bullet=$ evergreen oak, $\square=$ English oak. All values are mean of five trees, six leaves per tree. $L S D=$ least significant difference at $P \leq 0.05$. Species = *, salt, heat, Alpha Atrazine 50, and Diuron treatment $={ }^{*}$, species $\times$ treatment $=$ *. 


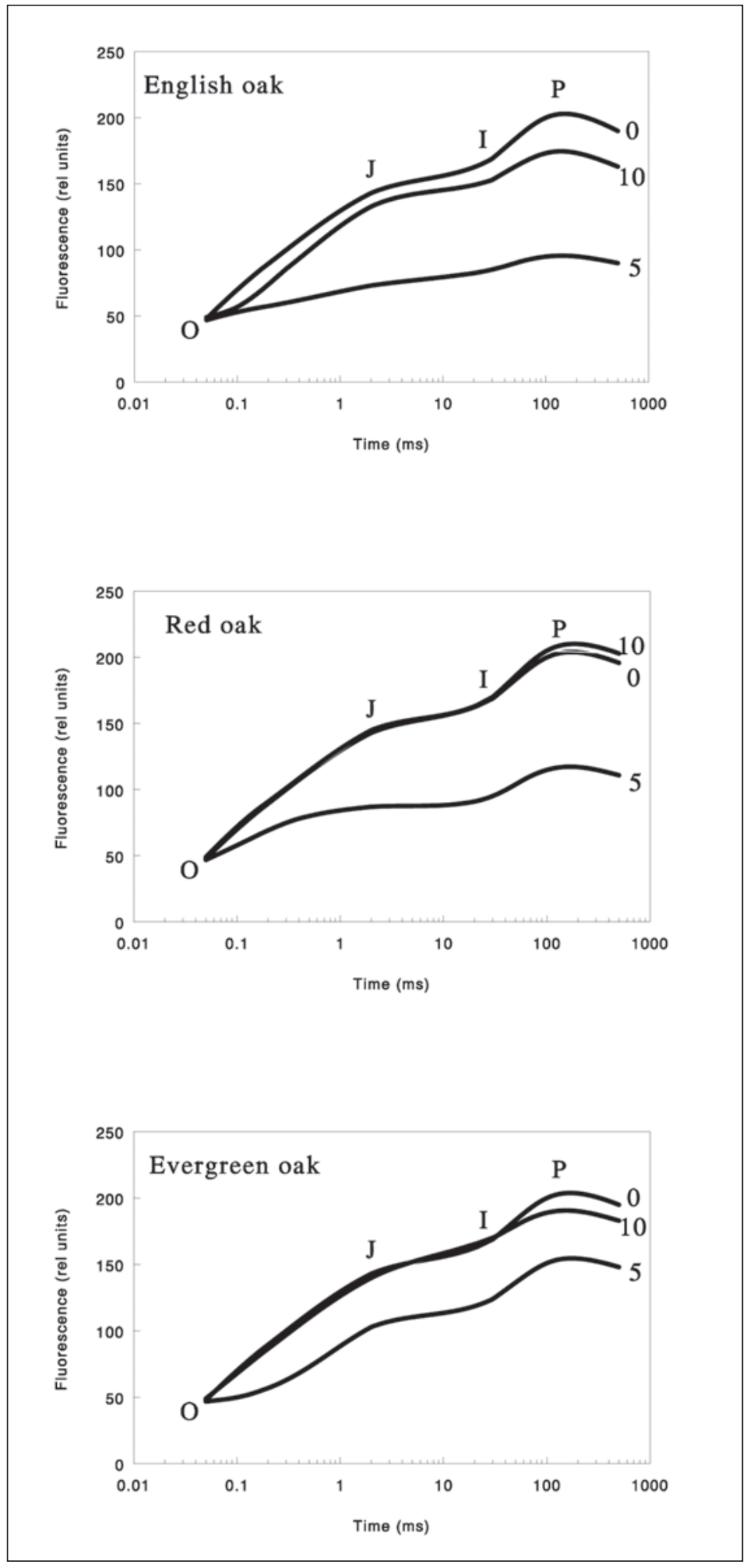

Figure 4. Alterations to leaf OJIP curves of English oak (Quercus robur L.), red oak ( $\mathcal{Q}$. rubra L.), and evergreen oak (Q. ilex L.) in response to salt damage at day 0 , week 5 , and week 10. All values are mean of five trees, six leaves per tree. 


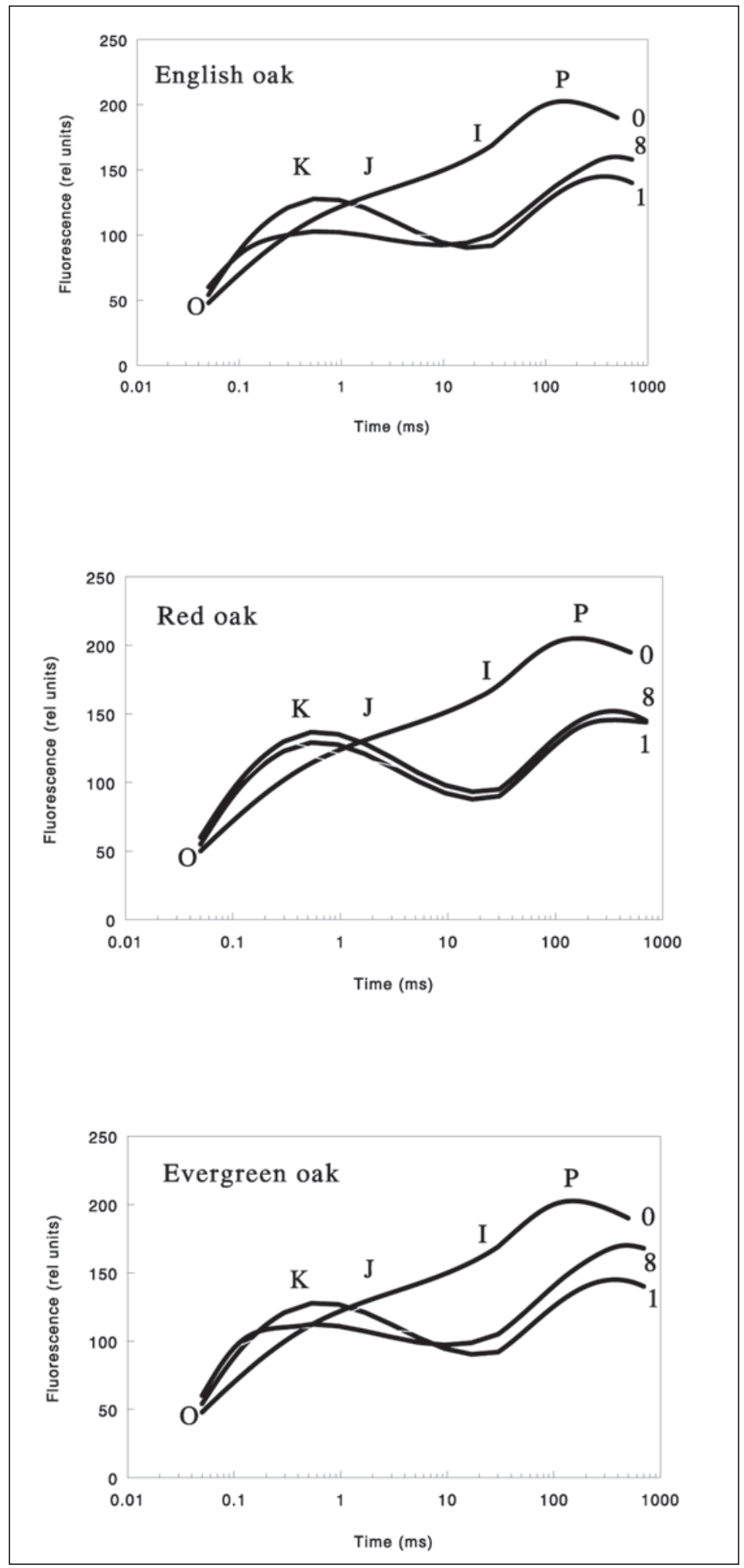

Figure 5. Alterations to leaf OJIP curves of English oak (Quercus robur L.), red oak (Q. rubra L.), and evergreen oak (Q. ilex $L_{\text {.) }}$ in response to heat damage at days 0,1 , and 8 . All values are mean of five trees, six leaves per tree. 


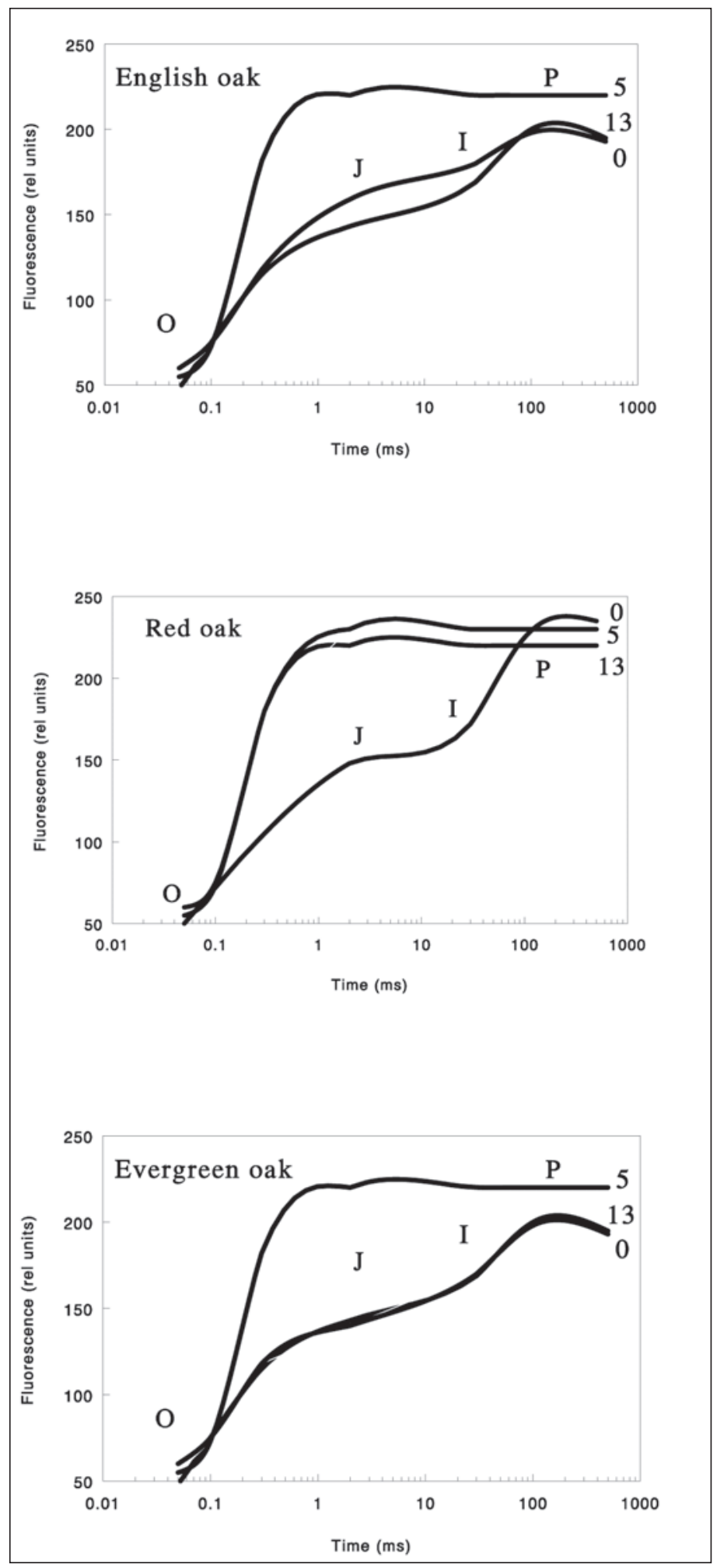

Figure 6. Alterations to leaf OJIP curves of English oak (Quercus robur L.), red oak (Q. rubra L.), and evergreen oak (Q. ilex $L$.) in response to Diuron damage at day 0 , week 5 , and week 13. All values are mean of five trees, six leaves per tree. 


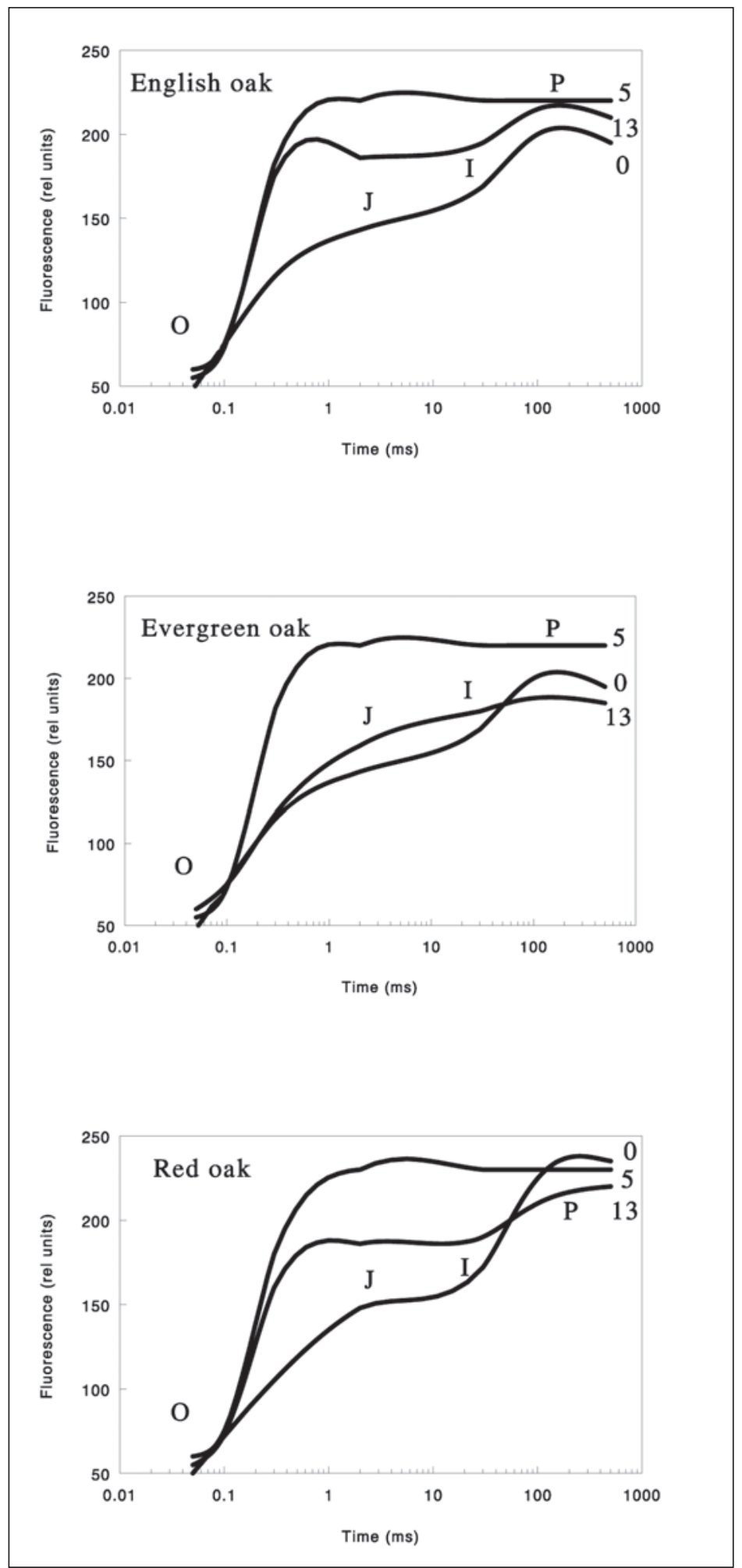

Figure 7. Alterations to leaf OJIP curves of English oak (Quercus robur L.), red oak (Q. rubra L.), and evergreen oak (Q. ilex L.) in response to Alpha Atrazine 50 damage at day 0 , week 5 , and week 13 . All values are mean of five trees, six leaves per tree. 